\title{
Promoting Scientific Cooperation in Times of Diplomatic Challenges: Sustained Partnership between the Cuban Academy of Sciences and the American Association for the Advancement of Science
}

\author{
Sergio Jorge-Pastrana, Marga Gual-Soler PhD, Tom C. Wang PhD
}

\begin{abstract}
Scientific research cooperation between Cuba and the USA has a long history that dates back to the 19th century. For the past 200 years, the two countries' relationship has been subject to complex economic, political and social forces. In the second half of the 20th century, the Cuban revolution and the subsequent escalation of the US government embargo impacted every aspect of Cuban life. While science was no exception, scientific interactions never ceased. Over the past decade, scientific cooperation-led and facilitated by scientific organizations such as the Cuban Academy of Sciences, the American Association
\end{abstract}

\section{HISTORICAL CONTEXT}

Science in Cuba and the USA developed in parallel following the process started earlier across the Atlantic with the European Enlightenment. Thus, by the time national scientific and cultural institutions were being established in the USA, the same was happening in Cuba. Nascent learned societies, such as Cuba's Academy of Sciences (then called the Royal Academy of Medical, Physical and Natural Sciences of Havana, the first academy of sciences established outside of Europe)[1] and the Smithsonian Institution early on established links for engagement in discussion, exchange of papers and materials, and sometimes parallel quests for new knowledge in both countries (letters exchanged beginning in the 1840s between Joseph Henry, First Secretary of the Smithsonian and Felipe Poey, a founding member of Cuba's Academy, are kept in the Smithsonian Archives).[2] While these links were somewhat frail, archives in both countries reveal that even then, US and Cuban scientists' interests went beyond country borders and found echoes in the activity of partners abroad, building friendships that continued in international scientific conferences to which both contributed papers and debates.

The most prominent scientific cooperation between the USA and Cuba during this early period was joint work by Cuban academician Carlos J. Finlay and Jesse Lazear of Johns Hopkins University, destined to prove Finlay's theories presented 20 years earlier on the mosquito as the vector for yellow fever transmission.[3] This in turn paved the way for needed sanitation efforts and eradication of this scourge, not only in Havana but also in Panama (where construction of the Canal was constantly delayed by epidemics

IMPORTANCE US-Cuba cooperation is essential. The two countries share emerging health and environmental challenges, and it is in both countries' interests to continue scientific engagement and knowledge exchange. Experience proves that commitment by their scientific communities can overcome political barriers. for the Advancement of Science and others-has steadily increased to address ever more critical issues facing both countries. Science and global health diplomacy were key to reestablishing a trusting and productive relationship of mutual and global benefit after the USA and Cuba restored diplomatic relations in 2015. However, recent changes in Cuba policy by the new US administration are jeopardizing these opportunities for increased scientific cooperation, which are in the best interests of people in both countries.

KEYWORDS International cooperation, academies and institutes, Cuba, USA

that crippled the workforce), and in many tropical areas afflicted by cyclic vector-borne disease crises with every rainy season.

This collaboration may be cited as an early example of science diplomacy for several reasons. Internationally, Finlay first presented his thesis on vector transmission at the 5th International Sanitary Conference in Washington, DC in February 1881. The meeting was convened for diplomats and physicians to discuss international spread of communicable diseases and epidemics. Finlay contributed to the discussion by explaining yellow fever transmission from sick to healthy subjects and his novel theory that the mosquitoes were the vector. Several months later, he presented his further-refined ideas to the Cuban Academy, results that were independently confirmed by Lazear, a member of the US military's sanitary commission headed by surgeon Major Walter Reed. Reed and other members of his commission initially favored the hypothesis of miasmatic contagion, but Finlay shared the results of all his previous experiments with the commission, enabling Lazear to independently corroborate his conclusions.

All this was accomplished in the difficult diplomatic situation provoked by the US military occupation of Cuba, in which the sanitary commission itself was part of this foreign intervention. Finlay was a local scientist attempting to contribute his discovery to end the continuous epidemics threatening Cubans, the US soldiers and the entire region, but his thesis contradicted the scientific understanding of the US commission's head and most of its members. In their rigorous pursuit of truth through science, Finlay and Lazear became "scientific diplomats," their complementary, confirmatory results overcoming political odds to solve a terrible public health problem.

Soon after the 1959 Cuban revolution, nearly 100 years after the Cuban Academy was established, the political divide between the USA and Cuba started to grow, leading to severed diplomatic relations. A cascade of divisive events ensued: an economic, trade and financial embargo that has escalated since 1961-62, the Bay of Pigs invasion, and the 1962 Missile Crisis. Relations that still existed among scientists virtually disappeared during those confrontational times. The Academy, reestablished after 1962 as 
the Cuban Academy of Sciences (ACC), with a broader scope and a mandate to foster research institutes, promoted studies in basic research and descriptions of Cuba's natural environment. Basic research in the fields of mathematics, physics, chemistry, geography, geology, geophysics, astronomy, meteorology, zoology, botany, and oceanography, as well as agricultural sciences, engineering and social sciences, were initiated by groups within the ACC.[1]

In the 1960s, Albert Sabin, best known for his research on polio and a pioneer in vaccine diplomacy, attempted to forge an agreement between ACC and the US National Academy of Sciences. Sabin received multiple invitations from Cuban public health officials during the early 1960s, but escalating hostility between the USA and Cuba made a high-profile visit by such a famous US scientist nearly impossible. However, when the US Department of State announced an easing of travel restrictions in 1965, in which medical researchers were included in the humanitarian exception to the travel ban, Sabin seized the opportunity to visit Cuba to promote greater cooperation in combating vector-borne diseases, hoping to serve as an interlocutor between senior officials in the two countries.[4]

By the 1970s, some links were reestablished between Cuban and US scientific institutions. Talks between ornithologists led by directors of the national zoos eventually produced bilateral visits between ACC and the Smithsonian Institution. The first memoranda of understanding (MOU) were signed by Cuban and US institutions in April 1980 when Dillon Ripley, Secretary of the Smithsonian, visited Havana. However, relations cooled once again with rising Cold War tensions in the following decade, effectively stifling the budding joint scientific endeavors and any hope to pursue normal relations among scientific colleagues.

Nevertheless, some researchers persisted in their efforts. Scientists from the National Museum of Natural History, the American Museum of Natural History, as well as several university and biomedical research centers, continued to partner with scientists in ACC institutes and some of the newly established biotechnology research facilities. Despite practical challenges to collaborative research, a steady increase in scientific discussion and jointly authored papers and books[5] continued to prove that, even in that difficult political environment, scientists sought and found ways to cooperate.

During the most tense periods, opportunities for increased cooperation were often facilitated by multilateral organizations in which the USA and Cuba were both members. For example, after facing bureaucratic barriers involving US Customs enforcement, Havana's Pedro Kourí Tropical Medicine Institute, with PAHO's assistance as intermediary, transported strains of dengue virus from Cuba's 1981 epidemic for further study at the US National Institutes of Health $(\mathrm{NIH})$. Several months later, in collaboration with $\mathrm{PAHO}$ and $\mathrm{WHO}$, Cuba hosted the first international course on dengue, launching a new era in international cooperation on dengue-related research, education and innovation that has benefited both Cuban and US researchers for over 30 years.[6]

In the 1990s, after the end of the Cold War, new opportunities for increased cooperation appeared, again facilitated by multilateral organizations such as the Inter-American Institute for Global Change Research (IAI) of which both Cuba and the USA were founding members. [6] At its creation in 1992, IAI was envisaged as an instrument for scientists and decision makers in the Americas to jointly frame, understand and tackle critical cross-border and regional issues associated with global change and their socioeconomic implications. The 19 member countries that formed the intergovernmental organization would fund collaborative research, training and policy-relevant communication. Thus, the IAI provided a multilateral forum for the USA and Cuba to interact scientifically when bilateral collaboration was not possible.

Also at that time, links were reestablished, or new ones established, between ACC and several US research institutions such as the American Museum of Natural History, the Social Sciences Research Council, the New York Botanical Garden (in 1994 ACC signed an MOU with the New York Botanical Garden, its signatories Brian Boom and Sergio Jorge Pastrana), and a growing number of US universities. Meanwhile, cooperation in the social sciences increased continuously through annual meetings of the Latin American Studies Association.

However, diplomatic and economic obstacles due to the continued US embargo on Cuba limited these collaborations' scope and reach. Although there were exceptions for certain types of medical and academic exchanges, US sanctions restricted Cuban researchers' ability to buy scientific equipment and access certain international grants, and limited US researchers' ability to use US government research funds and to co-organize meetings with Cuban counterparts.

It was under these difficult conditions that the American Association for the Advancement of Science (AAAS) and ACC intensified their cooperation.

\section{BILATERAL COOPERATION IN THE 21ST CENTURY:}

\section{ACC AND AAAS}

In 1992, William T. Golden, then an AAAS officer (described by The New York Times as "a main architect of American science policy in the 20th century"),[7] visited Cuba and participated in events commemorating an ACC anniversary. During the trip, he explored initial possibilities for establishing permanent links between the two institutions. This was followed in 1996 by a meeting between AAAS President Rita Colwell and the Cuban delegation to the General Assembly of the International Council for Science in Washington D.C. After these initial explorations, Colwell led the first AAAS delegation to Cuba in 1997. The visit focused on understanding the development of biomedical sciences and the biotechnology industry in Cuba, but also led to broader recommendations, including calls on US and Cuban authorities to ease restrictions on scientific travel.[8,9]

In 1998, AAAS published a report by Edward Kaufman and Elisa Muñoz that documented substantial hurdles for scientists wishing to travel between the USA and Cuba.[10] From then through 2002, AAAS sought to support scientists' rights to such travel, through its Latin American and Caribbean Program and its Human Rights Program, The project provided an online clearinghouse for information about cases where scientists were prevented from traveling to scientific conferences and meetings at partner institutions in the two countries.

At the turn of the 21st century, AAAS, ACC and other counterpart institutions devoted joint efforts to increasing scientific cooperation 
within the Caribbean region. At the 2002 AAAS Annual Meeting in Boston, an ACC delegation was invited to present opportunities for cooperation at a roundtable. In attendance were Golden, Colwell, Pastrana and Guadalupe Guzmán (the latter from Cuba's Pedro Kourí Tropical Medicine Institute in Havana), who were all involved in previous efforts to increase cooperation. By this time, scientific communities in both countries had already recognized for over a decade the importance of increased cooperation for the benefit of both societies.[11]

The second decade of the 21st century brought intensified efforts by AAAS and ACC to achieve more systematic cooperation. Starting in 2009, led by Nobel laureate and then AAAS President Peter Agre and AAAS Chief International Officer Vaughan Turekian, and carried forward by successive AAAS leaders (including another president, Gerald Fink) a series of scientific meetings and delegation visits culminated in April 2014 with a historic MOU between the two organizations, signed by AAAS CEO Alan Leshner and ACC Executive Director Sergio Jorge Pastrana.[12]

This formal agreement opened a path for increased and continuous cooperation in several priority areas of biomedical research that were of common interest and were recognized as paramount in both countries. Moreover, the series of visits leading up to the MOU involved other US scientific institutions (effectively broadening interaction between potential US and Cuban partners) and included Frances Colón, acting Science and Technology Adviser to the US Secretary of State; Colón was the highest-level US science diplomat to visit Cuba in an official capacity before the 2015 restoration of diplomatic relations.

By December 17, 2014, when US President Barack Obama and Cuban President Raúl Castro announced the beginning of a process to normalize bilateral relations[13] and brought hope for easing cooperation to both scientific communities, strong links among scientific leaders of both countries were already firmly in place.

Under the ACC-AAAS MOU, three USA-Cuba bilateral workshops have been held on neurosciences,[14] cancer immunotherapy[15] and vector-borne diseases[16] to foster interactions between leading researchers in both countries that could lead to increased and longterm programs of joint research. Individuals and institutions involved in these workshops have continued to maintain contact and interact, but they could benefit from an improved climate for cooperation that would allow for joint funding applications, research mobility, joint training, and shared laboratory instruments and techniques. To this end, in 2016 the AAAS Center for Science Diplomacy launched a pilot Cuban Biomedical Fellows Program, funded by the Richard Lounsbery Foundation in the USA, as the first structured exchange program supporting early- and mid-career Cuban biomedical scientists to conduct research visits to top US laboratories, with the expectation that this would lead to long-term collaborations between leading Cuban and US research institutions.

\section{CURRENT SITUATION AND PROSPECTS}

Reestablishment of diplomatic ties between the USA and Cuba in 2015 and ensuing policy revisions by the Obama administration prompted expanded scientific cooperation and new types of cooperation, by general authorization for joint commercial as well as non-commercial medical research and, for the first time, for Cuban-developed medications to enter normal FDA regulatory channels. The US Department of the Treasury also granted licenses for clinical trials in the USA of specific Cuban medications. $[17,18]$ The US NIH had also initiated a small number of relatively small grants to be administered by CRDF Global,[19] a US NGO that implements international scientific cooperation programs. The latter would have helped foster long term programs of bilateral scientific cooperation.

In addition, the US Department of Health and Human Services[20] and National Oceanic and Atmospheric Administration together with the Ministries of Health and of Science, Technology and Environment, their Cuban counterparts, signed intergovernmental MOUs to pursue scientific cooperation in public health and environmental sciences, including joint monitoring of coral reef ecosystems to better understand the consequences of climate change in the shared marine ecosystems across the Florida Straits, and an MOU particularly focused on cancer research.[21] Although the basis for joint research had already been laid by individual scientists and their institutions, for the first time in five decades, many nongovernmental organizations on both sides saw opportunities for regular cooperation. Long-term scientific cooperation emerged in key areas of mutual interest; more than half of the agreements signed during this brief period were preceded by earlier contacts between scientists trying to find ways for constructive cooperation. Those relations were maintained through challenging times by the shared interests of individuals and institutions. This proved once again, as evident many times in the past, that scientists and their discussions have been essential for gaining understanding among nations of different political, cultural and social environments.

Today, three years after restored diplomatic relations, the atmosphere for cooperation is once again uncertain. In October 2017, the new US administration halted rapprochement with Cuba, implementing revised policies that, while not explicitly targeting science, severely limit travel and logistical aspects of traveling between Cuba and the USA. The administration's decision to close its consular services for Cubans at the US Embassy in Havana means that Cubans must travel to a third country to apply for a US visa.[22] These moves will likely discourage both sides from pursuing joint research, a deterrent to scientific cooperation.

During these uncertain times, a new kind of relationship continues to be built between scientists of the two countries that, though close geographically, have been as widely separated for more than half a century as if they were on different continents. Scientific communities in both countries have repeatedly reinforced the need to continue to find ways to promote collaboration that could contribute to addressing shared national and regional challenges.

Such cooperation is essential: Cuba and the USA are inextricably linked. The two nations share emerging health and environmental challenges, and their common backyard is an ocean filled with limited resources. During difficult times in the history of the US-Cuba relationship, scientists have worked to keep partnerships alive in the face of changing and often destructive policies. It will be in both countries' interests to continue US-Cuban knowledge exchange and facilitate deeper engagement between scientists to benefit people in Cuba, the USA and well beyond. Scientific institutions of both countries will undoubtedly continue to promote and defend scientists' rights to share their knowledge and experience in the search for new truths vital to solving urgent problems faced by the two countries and the planet as a whole.[23] $-1 /$ 


\section{REFERENCES}

1. Academia de Ciencias de Cuba [Internet]. Havana: Academia de Ciencias de Cuba; c2015. Historia; [cited 2017 Dec 24]; [about 1 screen]. Available from: http://www.academiaciencias.cu/ es/historia?tipo=Resumen. Spanish.

2. Pastrana SJ. Building a lasting Cuba-US bridge through science. Science and Diplomacy [Internet]. 2015 Mar 30 [cited 2017 Dec 24]; [about 10 pages]. Available from: http://www.sciencedi plomacy.org/perspective/2015/building-lasting -cuba-us-bridge-through-science

3. Chávez-Carballo E. Carlos Finlay and yellow fever: triumph over adversity. Military Med. 2005 Oct;170(10):881-5.

4. Jiménez M. Epidemics and opportunities for U.S.-Cuba collaboration. Science \& Diplomacy [Internet]. 2014 Jun 9 [cited 2017 Dec 24];3( 2). Available from: http://www.sciencediplomacy.org/ article/2014/epidemics-and-opportunities-for-us -cuba-collaboration

5. Arencibia R, Corera E, Vega RL. Puentes científicos entre Cuba y los Estados Unidos. Rev Cub Información Cienc Salud [Internet]. 2017 [cited 2017 Dec 22];28(2). Available from: http://www.rcics.sld.cu/index.php/acimed/article/ view/1109/674. Spanish, English.

6. Gual Soler M. Intergovernmental scientific networks in Latin America: supporting broader regional relationships and integration. Science \& Diplomacy [Internet]. 2014 Dec 22 [cited 2017 Dec 24];3(4). Available from: http://www.scien cediplomacy.org/article/2014/intergovernmental -scientific-networks-in-latin-america

7. Overbye D. William T. Golden, Financier and Key Science Adviser, is Dead at 97. New York: New York Times; 2007 Oct 9 [cited 2017 Dec 24]. Available from: http://www.nytimes.com/2007/10/09/ us/09golden.html

8. American Association for the Advancement of Science (AAAS). Biotechnology in Cuba: A Report on a Scientific Mission to Cuba, June 28July 4, 1997. New York: AAAS; 1998.

9. JewettS. U.S. and Cuba asked to ease restrictions. Science [Internet]. 1998 Apr 10 [cited 2017 Dec 22];280(5361):189. Available from: http://scien ce.sciencemag.org/content/280/5361/s-scope

10. Muñoz E. The right to travel: The effect of travel restrictions on scientific collaboration between American and Cuban scientists. Washington, D.C.: AAAS Science and Human Rights Program; 1998.

11. Pastrana SJ, Clegg MT. U.S.-Cuban scientific relations. Science [Internet]. 2008 Oct 17 [cited 2017 Dec 24];322(5900):345. Available from: http://science.sciencemag.org/con tent/322/5900/345.full
12. Fink GR, Leshner Al, Turekian VC. Science diplomacy with Cuba. Science [Internet]. 2014 Jun 6 [cited 2017 Dec 22];344(6188):1065. Available from: http://science.sciencemag.org/con tent/344/6188/1065

13. The Washington Post. Transcript: Obama's remarks on U.S.-Cuba relations on December 17, 2014. The Washington Post [Internet]. 2014 Dec 17 [cited 2017 Dec 22]; [about 6 screens]. Available from: https://www.washingtonpost.com/poli tics/transcript-obamas-remarks-on-us-cuba-re lations/2014/12/17/08366538-8612-11e4-9534 -f79a23c40e6c_story.html?utm_term=.dc3a $0 \mathrm{e} 7534 \mathrm{db}$

14. Ham B. U. S. and Cuban researchers begin neuroscience collaborations. Science [Internet]. 2016 Jan 29 [cited 2017 Dec 22];351(6272):45859. Available from: http://science.sciencemag .org/content/351/6272/458.full?_utma $=897781$ 87.1683033713 .1512421091 .1512421091 .151 2421091.1\&_utmb=89778187.2.9.151242116 7698\&_utmc $=89778187 \&$ _utmx $=-\&$ _utmz $=$ 89778187.1512421091.1.1.utmcsr=google|utm $\mathrm{ccn}=($ organic $) \mid$ utmcmd $=$ organic $\mid$ utmctr $=($ not $\% 20$ provided)\&_utmv $=-\&$ _utmk $=72728538$

15. Hoy AQ. U.S. and Cuban scientists explore advances to fight cancer. AAAS [Internet]. 2016 Jun 10 [cited 2017 Dec 24]; [about 3 screens]. Available from: https://www.aaas.org/news/us-and -cuban-scientists-explore-advances-fight-cancer

16. Jarvis M. U.S.-Cuba Meeting demonstrates value of collaboration in science. AAAS [Internet]. 2017 Aug 23 [cited 2017 Dec 24]; [about 5 screens] Available from: https://www.aaas.org/news/us -cuba-meeting-demonstrates-value-collabora tion-science

17. New York State [Internet]. New York: State of New York; c2018. Governor Cuomo announces groundbreaking clinical trial of Cuban-developed lung cancer treatment at Roswell Park Cancer Institute in Buffalo; 2016 Oct 26 [cited 2017 Dec 24]; [about 4 screens]. Available from: https:// www.governor.ny.gov/news/governor-cuomo -announces-groundbreaking-clinical-trial-cuban -developed-lung-cancer-treatment

18. U.S. Department of Treasury [Internet]. Washing ton, D.C.: U.S. Department of Treasury; c2018. U.S. Department of Treasury Resource Center. Publication of updated Cuban Assets Control Regulations (CACR); 2016 Oct 14 [cited 2016 Dec 13]. Available from: https://www.treasury .gov/resource-center/sanctions/OFAC-Enforce ment/Pages/20161014.aspx

19. CRDF Global [Internet]. Virginia: CHRF Global; c2018. Information for Applicants. U.S.-Cuba Collaborative Arbovirus Research Initiative; 2017 [cited 2017 Dec 24]; [about 2 screens]. Available from: http://www.crdfglobal.org/funding-opportu nities/US-CubaArbovirusInitiative2017

20. Bausch DG, Kourí V, Resik S, Acosta B, Guillén G, Goraleski K, et al. The Cuba-United States thaw: building bridges through science and global health. Am J Trop Med Hyg [Internet]. 2017 Jun 7 [cited 2017 Dec 24];96(6):1267-9. Available from: https://www.ncbi.nlm.nih.gov/pmc/articles/ PMC5462558/

21. NOAA [Internet]. Maryland: NOAA; c2018. Press Release. National Marines Sanctuaries. U. S. and Cuba to Cooperate on Sister Sanctuaries: [cited 2017 Dec 24]; [about 3 screens]. Available from: https://sanctuaries.noaa.gov/news/nov15/ us-and-cuba-to-cooperate-on-sister-sanctuaries html

22. Jarvis M. U.S. Policy on Cuba obstructs crucial breakthroughs in Alzheimer's, cancer. AAAS [Internet]. 2018 Jan 25 [cited 2017 Dec 24]; [about 3 screens]. Available from: https://www.aaas. org/news/us-policy-cuba-obstructs-crucial-break throughs-alzheimers-cancer

23. Holt R, Pastrana SJ. Science can bring CubaU.S. together. Orlando Sentinel [Internet]. 2016 Mar 22 [cited 2017 Dec 24]; [about 3 screens]. Available from: http://www.orlando sentinel.com/opinion/os-ed-cuba-science-diplo macy-032216-20160321-story.html

\section{THE AUTHORS}

Sergio Jorge-Pastrana (Corresponding author: pastrana@ceniai.inf.cu), historian. Executive Director, Cuban Academy of Sciences, Havana, Cuba.

Marga Gual-Soler PhD, molecular biologist. Project Director, Center for Science Diplomacy, American Association for the Advancement of Science (AAAS), Washington, DC, USA

Tom C. Wang, chemical engineer and political scientist. Chief International Officer and Director, Center for Science Diplomacy, AAAS, Washington, DC, USA.

Submitted: February 7, 2018

Approved for publication: March 25, 2018 Disclosures: None 